\title{
SOCIAL MEDIA IN BANKING. A MANAGERIAL PERCEPTION FROM MEXICO
}

\author{
Doina DĂNĂIAȚĂ 1 \\ Camelia MARGEA 2 \\ Kristine KIRAKOSYAN 3 \\ Ana-Maria NEGOVAN 4
}

DOI: 10.1515/tjeb-2015-0009

\begin{abstract}
Nowadays social media has a radical impact on the business world, becoming a great customer service tool across many industries. And banking is no exception. Thus, banks managers need to identify ways to make profitable use of the social media. By accepting the benefits and developing their presence in social media, banks will be closer to customers. The objective of our research is to study social media usage in the banking industry and to obtain a managerial view concerning barriers and challenges in the social media implementation process. From the research of the literature in the field, we observed that Social media was studied a lot from the customers' point of view, but there are not many studies on social media from a managerial point of view. This article presents a part of our research results regarding social media usage in banking in different regions of the world, specifically, the Mexican banking sector. We conducted a qualitative research based on interviews carried on among 20 banks from Mexico. The goal was to see how the decision factors in banks perceive the social media usage for their institution and for the banking industry, in general. The study focuses on the barriers and challenges raised by the existence and usage of social media platforms. The findings revealed an important presence of the Mexican bank industry in social media areas, but with a lot of room for extending the banks' presence in new Social Media platforms, and different degrees regarding the perception of barriers and challenges in adopting Social Media tools.
\end{abstract}

Keywords: $\quad$ social media, banking industry, management opinion, barriers, challenges.

\section{JEL Classification: G21, 033.}

\footnotetext{
${ }^{1}$ Professor PhD, West University of Timisoara, Romania

${ }^{2}$ Lecturer PhD, West University of Timisoara, Romania

${ }^{3,4}$ PhD Student, West University of Timisoara, Romania
} 
Dănăiață, D., Margea, C., Kirakosyan, K., Negovan, A.-M. of Economics and Business

Social Media in Banking. A Managerial Perception from Mexico

\section{Introduction}

Social Media (SM) has become a research topic for many areas, the banking area being no exception. There may be different attitudes towards its usage, but there is undoubtedly one thing: the banking strategy should not ignore social media or to try to escape from conversation, but to be active and effective on all social media platforms.

The Global Retail Banking Digital Marketing Survey conducted by Efma \& Wipro (2013) in 100 banks from 38 different countries, shows that there has been an implacable growth in electronic banking around the world, with access rates reaching over $80 \%$ of adults in some countries using online banking regularly. The involvement in social media starts to become a standard practice for banks. The great challenge is to achieve effective "customer engagement", which means developing more significant digital interaction with customers, as an alternative to the traditional face-to-face interactions of banking.

The majority of analysts and bloggers are convinced that banks simply missed the opportunity for jumping on the social media bandwagon. Nadkarni (2013), in his article "Avoiding Social Media Will Cost Banks Customers", pointed out that "thanks to social media channels" the sale process changed drastically, banks losing the "control of the sales process" - "Rather than meeting with a sales representative to discuss a bank's offerings and services, customers are relying on Facebook, Twitter, Google+ and other channels to decide what brand they want to bank with".

Banks need to start taking the social media industry seriously and develop a clear strategy. But the area is full of gaps and needs many more efforts and attitude from the banks. The challenge is the "how to" in such a highly regulated industry. In less than a few years the daily business will be conducted from anywhere at any time on mobile devices. Any business needs to adjust to these demands and be available respectively. Due to reasons of security, compliance, and risks, the majority of banks have made a pass through on this communication channel so far, but social media allows banks to connect with their customers in a completely new manner.

Some banks have already started to use social media for providing information about products and generating leads, even for providing transactional services. The fact is that nowadays in the banking area it is difficult to create new markets, so banks focus on their products and existing customers. Customers are the most important stakeholders for banks. By taking into consideration that Social Media has a huge impact on today's business world, E-banking management needs to identify ways to make profitable use of the social media: applications such as Facebook, Twitter, Google+, YouTube, etc.

In our study, we tried to expose the situation regarding the SM usage in Mexican banks, analyzing the banks' presence in SM platforms and the managerial perception regarding barriers and challenges in adopting SM in the banking system.

\section{DE GRUYTER OPEN}

Timisoara Journal of Economics and Business | ISSN: 2286-0991 | www.tjeb.ro Year 2014 | Volume 7 | Issue 2 | Pages: 147-174 
Dănăiață, D., Margea, C., Kirakosyan, K., Negovan, A.-M.

Social Media in Banking. A Managerial Perception from Mexico

The next parts of this paper include: first - a synthesis of the main academics' and practitioners' works in the researched field (SM in banking), second - the particularities of SM usage in Mexico (the country chosen to conduct our research), the third part is the main one and was dedicated to the research methodology and findings, and ended with conclusions and future developments. In the Appendix we presented the results from the statistical analyses performed for testing our hypotheses.

\section{The Added Value of Social Media for the Banking Industry}

In this part we developed a literature review concerning the added value of Social Media for the banking industry, pointing out the aspects we considered essential on this issue (see Table 1).

Table 1. Added Value of Social Media for Banking

\begin{tabular}{|c|c|}
\hline Added value & Source \\
\hline - Customer engagement & Efma \& Wipro (2013) \\
\hline - An important foundation of commerce & Weinberg \& Pehlivan (2011) \\
\hline - An increasingly popular source of banking information & Ernst \& Young (2012) \\
\hline - Conversations to reach a wider audience & $\begin{array}{l}\text { Edosomwan, Prakasan, Kouame, Watson, } \\
\text { \& Seymour (2011) }\end{array}$ \\
\hline - A cost-effective method for marketing activities & Paridon \& Carraher (2009) \\
\hline $\begin{array}{l}\text { - Deeper, interpersonal relation and communication } \\
\text { with customers }\end{array}$ & $\begin{array}{l}\text { Merrill, Latham, Santalesa \& Navetta (2011), } \\
\text { Lemon and Rust (2001), Vaynerchuk (2009), } \\
\text { King (2013) }\end{array}$ \\
\hline - Reach the largest number of potential customers & Kirakosyan (2014) \\
\hline - Crowdsourcing & Merchant (2013), Alampi (2012) \\
\hline - Human Resources & Kaplan \& Haenlein (2010) \\
\hline - Innovative and creative marketing & $\begin{array}{l}\text { Smith, Wollan \& Zhou (2011), } \\
\text { Kietzmann (2011) }\end{array}$ \\
\hline - Monitor public awareness & Kirakosyan (2014) \\
\hline - Lead to a sales conversion & Leonard \& Youra (2013) \\
\hline - Boost traffic to the website of the organization & Elliott (2013) \\
\hline - Customer co-creation & He \& Yan (2014) \\
\hline - CRM & Thomas (2010), Brown (2012) \\
\hline - Cross-selling & Hensel \& Deis (2010) \\
\hline - Business process management & Pearson (2013) \\
\hline - Prediction of stock market performance & Jiang, Liang, Chen \& Ding (2012) \\
\hline - Trust restore in the financial markets & Shetty (2013) \\
\hline - Influences investors searching for deals. & Taten \& Farmer (2012) \\
\hline
\end{tabular}


Dănăiață, D., Margea, C., Kirakosyan, K., Negovan, A.-M.

The authors of this paper are involved in researching the added value of Social Media in the banking industry. In this article we focus on the usage of Social Media in the Mexican banks and on the barriers and challenges perceived by the managers of the banks.

Considering the reduced number of academic papers focusing on SM usage in the banking system, we would like to underline the importance of having access to valuable data from some important worldwide reports in our research field during the most recent period of time (20122014), data which is presented in Table 2.

Table 2. Worldwide Reports in Banking and Social Media

\begin{tabular}{|c|c|c|c|}
\hline Source & Report title & 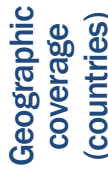 & Sample \\
\hline Ernst \& Young (2012) & Global Consumer Banking Survey 2012 & 35 & 28,500 banking customers \\
\hline Efma \& Wipro (2013) & $\begin{array}{l}\text { Global Retail Banking Digital Marketing } \\
\text { Report } 2013\end{array}$ & 38 & 100 banks \\
\hline Capgemini \& Efma (2013) & 2013 World Retail Banking Report & 35 & 18,000 customers \\
\hline Ernst \& Young (2014) & Global Consumer Banking Survey 2014 & 43 & 32,000 retail banking customers \\
\hline We Are Social Ltd (2014) & Global Digital Statistics 2014 & 24 & the world's largest economies \\
\hline Capgemini \& Efma (2014) & 2014 World Retail Banking Report & 32 & 17,000 retail banking customers \\
\hline
\end{tabular}

The important findings selected from these global reports were used in the practical research to elaborate a set of hypotheses regarding the SM recognition and awareness in the banking industry, those hypotheses being tested on a sample that included a total number of 20 retail banks in Mexico. We mention that after this pilot testing in one country, we extended our practical research to two other countries. We wanted to see if the hypotheses are globally tested and to pursue a comparative analysis between SM usage in different countries, with different economic levels of development, and different level of SM dissemination/diffusion.

\section{Social Media Usage in Mexico. Country Profile}

Mexico was the country chosen for conducting our first empirical research, so we would consider it important to analyze the specificity of this Latin American country regarding social media usage in general, and of course in the banking sector, the field of our interest.

In Latin America internet usage is growing very rapidly. World Bank indicators showed that Argentina, Brazil, Mexico, and Colombia register the highest rates of internet usage in the

\section{DE GRUYTER OPEN}

Timisoara Journal of Economics and Business | ISSN: 2286-0991 | www.tjeb.ro Year 2014 | Volume 7 | Issue 2 | Pages: 147-174 
region. Based on a report from September 2011 - "The Rise of Social Networking in Latin America", Domingues (2013) found that, according to the time spent on social networking, half of the top ten worldwide markets are in Latin America.

Mexico has its unique place in this growth. In October 2012, when Facebook registered over 1 million users, 19 percent of those users lived in Latin America. We consider as encouraging signs in using social media the fact that "Mexico is the first country in Latin America where the president and the cabinet became engaged in social media" (Dominguez, 2013).

The governments of virtually all large Latin American cities now use social media to interact with the citizens, and smaller cities are quickly following their example. The Inter-American Development Bank recently found that social media is used by governments of Latin American in 70 percent of the region's 140 "emerging cities" - having 100,000 to 2 million residents and above-average economic growth rates. (Moreno, 2012)

According to the Global Digital Statistics (We Are Social Ltd., 2014), in Mexico only Facebook users, who by the way are active ones,-register a number of 50,000,000. This means, in Mexico approximately 43 percent of the population is using Facebook. And this, without taking into consideration that $27.4 \%$ of the population belongs to the age group of $0-14$ years (www.indexmundi.com). This means that, if we consider the large number of Facebook users in Mexico, based on this social media banks can target around $43 \%$ of the population.

According to the statistics, $33 \%$ of the Mexican population spend on average $5 \mathrm{~h} 22 \mathrm{~m}$ on the internet every day, of which around $3 \mathrm{~h} 46$ minutes they use social media, an additional argument in order that banks should not overlook the role of their presence in Social Media. Table 3 presents the overall social media usage in Mexico, and we can see that Facebook is at the top of the list.

Table 3. Social media usage in Mexico

\begin{tabular}{lrc}
\hline & Own an account (\%) & Used in the past month (\%) \\
\hline Any social network & $98 \%$ & $72 \%$ \\
FACEBOOK & $94 \%$ & $61 \%$ \\
GOOGLE+ & $74 \%$ & $29 \%$ \\
TWITTER & $62 \%$ & $27 \%$ \\
LINKEDIN & $36 \%$ & $12 \%$ \\
INSTAGRAM & $28 \%$ & $8 \%$ \\
\hline
\end{tabular}

Source: Global Digital Statistics 2014 (We Are Social Ltd., 2014)

The survey "Digital Marketing and Social Networks in Mexico, 2013" performed by AMIPCI (Mexican Association of Internet) by administering questionnaires to 615 companies, having

DE GRUYTER OPEN
151

Timisoara Journal of Economics and Business | ISSN: 2286-0991 | www.tjeb.ro

Year 2014 | Volume 7 | Issue 2 | Pages: 147-174 
national representative coverage, with a confidence level of $95 \%$, shows that $85 \%$ use social networks, this meaning that 8 out of 10 companies have some social profile (i.e. 387 companies that have activities in digital marketing).

Based on the surveys including 328 companies that maintain any kind of profile in social networks, AMIPCI presented the main social media platforms where Mexican companies are present (see Figure 1).

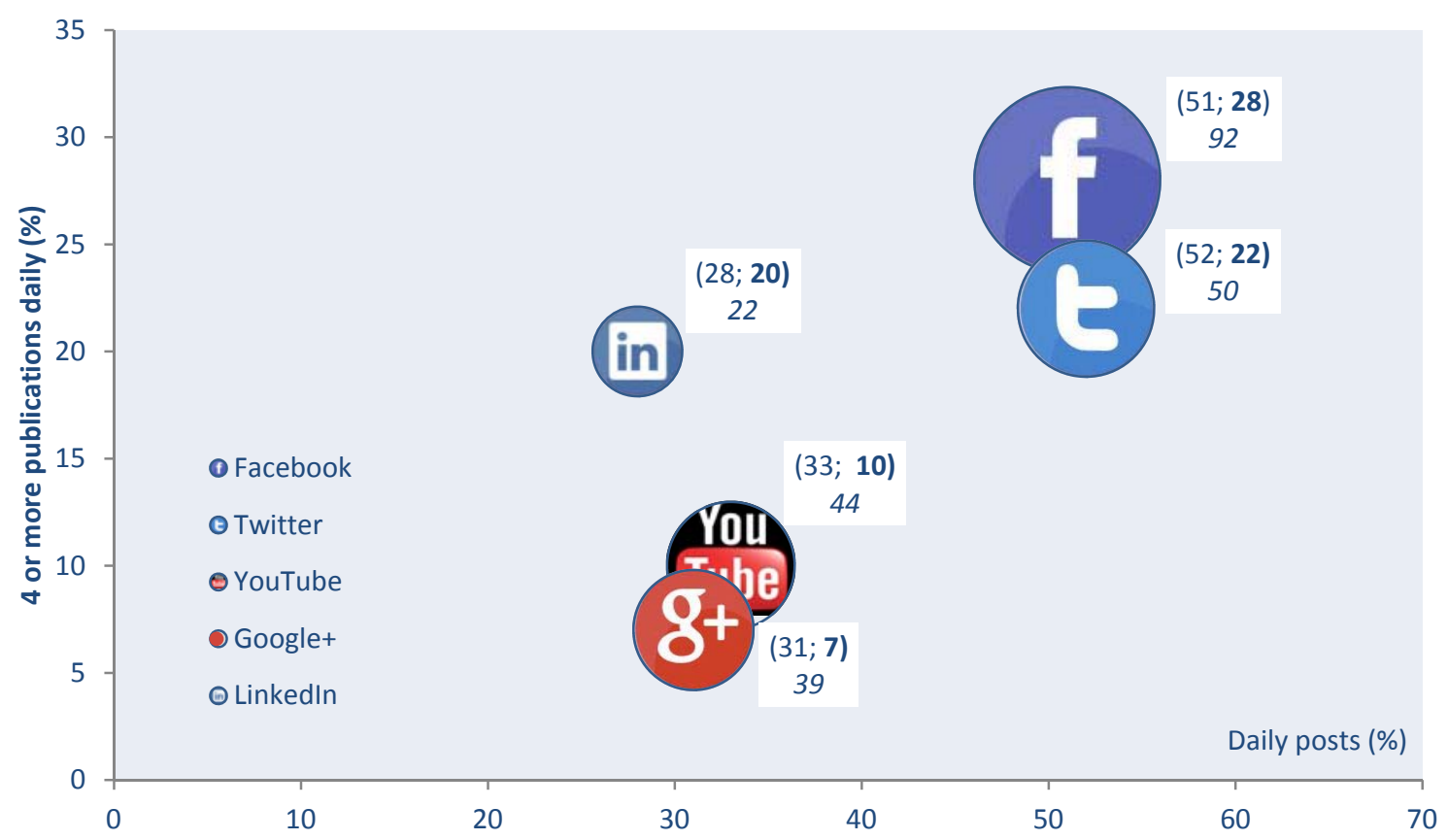

Figure 1. Main Social Media platforms

Source: adapted from AMIPCI, 2013

Note: size of bubbles represents Registered companies (\%) and is the last value label (italic font style) near each bubble

Only $13 \%$ of companies allot more than 20 hours in their social networking profiles per week, though $68 \%$ of companies have designated staff to manage their profiles (almost 7 from 10).

The survey "Digital Marketing and Social Networks in Mexico, 2013" performed among 5199 internet users found out that $93 \%$ of them use social media. The most popular social media platforms for internet users are Facebook, Twitter, YouTube, LinkedIn and Google+. Another important factor is the age in social media platforms. On average for the most popular platforms generally the age is $18-24$, followed closely by the age group 25-34.

In Mexico, 50\% of the Social Media customers are not passive users. They don't only look for information about products, but also pursue certain specific brands, being actually quite 
Dănăiață, D., Margea, C., Kirakosyan, K., Negovan, A.-M. of Economics and Business

Social Media in Banking. A Managerial Perception from Mexico

active on those companies' web sites. $40 \%$ also become avid fans up to becoming prosumers, actively involved in the decisions taken in case of some products.

Placing our research in this favorable national context regarding the Social Media use at both business and consumer level, we aimed to test the added value of Social Media use in banking industry (see Table 1, containing the specific issues identified in literature review).

\section{Research Methodology}

Our study is based on a survey conducted on a representative sample of Mexican banks, where interviews were conducted involving general managers, and managers responsible for Social Media. First, we researched the Mexican banks' presence in social media platforms. For this, we have chosen 20 Mexican and foreign-owned banks, most of them being representative for the Mexican banking system. In order to analyze the social networking websites used for communication, we have chosen Facebook, as it is the most popular among internet users. We focus our attention on the communication and the interaction with customers done by banks via their Facebook pages. The research has been done during 4 months, from March to June 2014.

The first thing that we checked was the banks' website and connection to their social media platforms. Thus, not all banks have connection to their social media platforms. We think that this is a weak point of social media management implementation. Banks should make it as easy as possible for customers to find them. And after presenting the statistics for social media usage, it is obvious that nowadays customers mainly activate on social media platforms. Some banks' web sites indicate a link to the social media platforms taking the audience to those platforms; on the other hand, some banks' web sites do not have this connection, thus confusing the audience in finding the real social media platform of that bank. We believe that the banks' management should take into consideration that not all internet users have enough internet usage skills to get to the website which they would want to reach, therefore an inappropriately managed communication could bring damage to both sides.

Some social media platforms, especially Facebook, are places where the audience wants to be entertained. The people are looking for promotions, special offers, free games and other applications, thus on their Facebook pages the banks need to communicate and entertain the audience. Some banks provide only news about banking products and exchange rates. The content of banks' Social Media involvement should be fresh, the banks needing to engage in dialogues with their customers. The participants are important. Social Media is not a place where you sell, it's a place where you create participation especially for your customers. Toffler (1980) first introduced the concept of "prosumers", to define the type of consumer engaged in social media applications, consumer which have the desire to actively engage and become both producers and consumers of information. Indeed, banks should not avoid being more active in Social media communication with customers. The Social Media

\section{DE GRUYTER OPEN}

Timisoara Journal of Economics and Business | ISSN: 2286-0991 | www.tjeb.ro Year 2014 | Volume 7 | Issue 2 | Pages: 147-174 
Dănăiață, D., Margea, C., Kirakosyan, K., Negovan, A.-M. of Economics and Business

Social Media in Banking. A Managerial Perception from Mexico

now is a great customer service tool across many industries and the banking sector is no exception.

To benefit from all the added values of SM usage presented in the theoretical part, first of all, the banks should recognize a need for social media taken together with its challenges, barriers and benefits. By recognizing a "need" of SM for banking activities the "wants" will be crated to fulfill that needs.

SM awareness and recognition should be the first stage that offers the basis for SM implementation and use.

\subsection{Social Media factors in awareness and recognition stage}

In this paper, we pay special attention to the barriers and challenges of SM adoption. There can be other issues that can be taken into consideration in the awareness phase, but we consider that if banks are aware of those two important criteria at this stage, they will have a solid base for the Social Media implementation strategy. Before presenting a set of the above-mentioned two important elements, we would like to emphasize that those are not fact-related, but cognitive-related ones. Different managers have different attitudes toward them and based on their attitude they make decisions on the SM implementation. Even if baking managers are not involved in the decision-making process (depending on the government model), they still influence that process. Thus, we consider it very important for banks to recognize and get acquainted with social media barriers and challenges.

Based on our theoretical research put forward in this article, we established the set of barriers (i.e., Lack of senior management understanding, Lack of a dedicated Social Media manager, Lack of skills and competencies within banks and Lack of strategy around the "usage" of Social Media) and challenges (i.e., Potential customer attainability in an easy and fast way, Innovative method for marketing activities, Advanced way for crowdsourcing, Fast way for the new competitors' and market's tracking, Customer care improvement, Customers' demand and behavior recognition). In the questionnaire, for all of them, there were multiple-choice options where from respondents selected all the categories applicable to them, as well as there were an additional option to add comments and other potential answers. However, in general, managers did not add many other answers. By this, we can assert that a set of these important elements are corrected and really represent the real picture of SM barriers and challenges that nowadays banks face.

Based on the conducted theoretical research, on the statistics and findings about SM usage, we put forward three main hypotheses. In order to test them we targeted to survey persons holding managerial positions or being SM representatives in banks.

\subsection{Hypotheses}

We would like to mention that as SM was not very much researched, especially for its usage in the banking sector, so besides testing our hypotheses we conducted as well an

\section{DE GRUYTER OPEN}


Dănăiață, D., Margea, C., Kirakosyan, K., Negovan, A.-M.

exploratory research. By this, we aimed to find out how different SM factors (variables) are influencing or, in their turn, are influenced by other variables. Therefore, we formulated three main hypotheses and four sub-hypotheses and findings, as presented in Table 4.

Table 4. Hypotheses with validations

\begin{tabular}{c} 
Hypothesis \\
\hline H1 $\quad \begin{array}{l}\text { Banks from the researched country are present in the main social media platforms, } \\
\text { but there is a lot of room for extending the banks presence in SM. }\end{array}$ \\
H2 $\quad \begin{array}{l}\text { Banks' managers do consider that social media adoption is affected by a set of } \\
\text { barriers. }\end{array}$ \\
H2a \\
H2b $\begin{array}{l}\text { The Managers' age is a factor that influences how they perceive barriers. } \\
\text { H } 3 \quad \text { The banks' managers consider that social media adoption brings about a set of } \\
\text { challenges for their banks. }\end{array}$ \\
H3a The Managers' age is a factor that influences how they perceive challenges \\
H3b The Managers' experience is a factor that influences how they perceive challenges.
\end{tabular}

\subsection{Sample}

We have interviewed a total of 40 managers in 20 Mexican banks (we gathered two answers from different managers in the surveyed banks). We studied and tested our samples by using statistical tools for frequencies, crosstabs, correlations, factor analysis, reliability analyses, as well as for finding out the influence for factors case in which we used general linear models (GLM). For each hypothesis and finding, we presented in the Appendix all the statistical tools used for the analyses, together with the tables representing the results.

As our research is dedicated not only to SM management and usage but also to its managerial view, for our survey we choose as respondent category managers (different managerial positions) as well as SM representatives.

The managerial characteristics of respondents are the age (Figure 2a), the experience in managerial position (Figure $2 b$ ), the level of education (Figure $2 c$ ) and the domain of study (Figure 2d). 
a) Age Distribution (years)

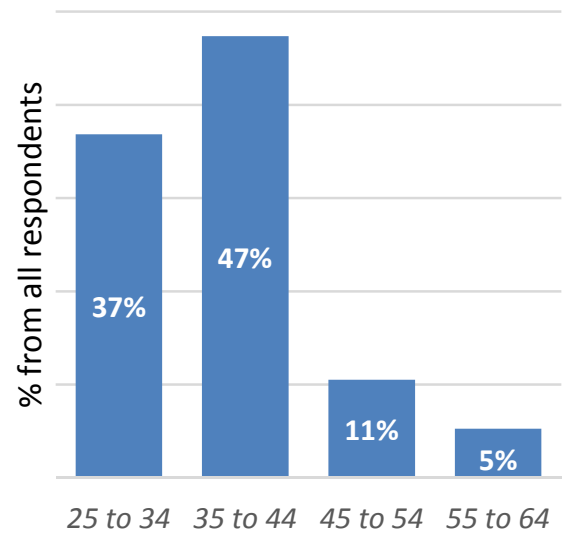

c) Graduation Level

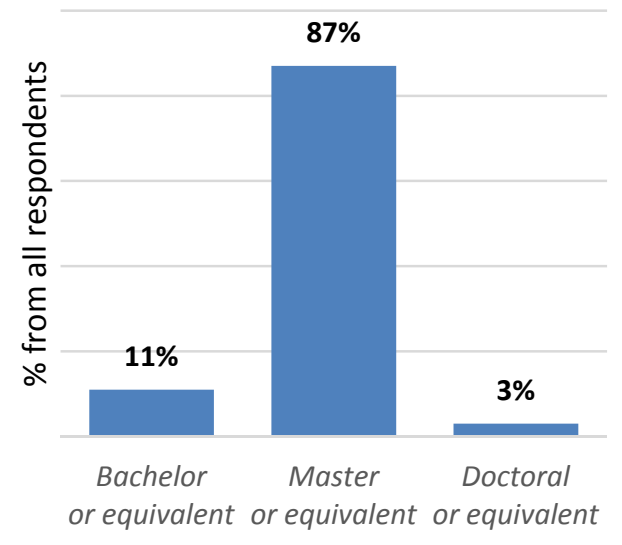

b) Experience in Managerial Position (years)

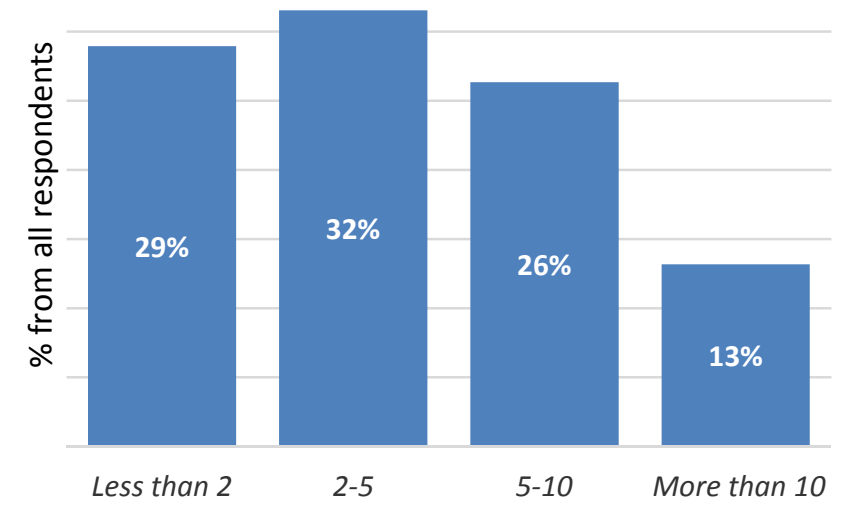

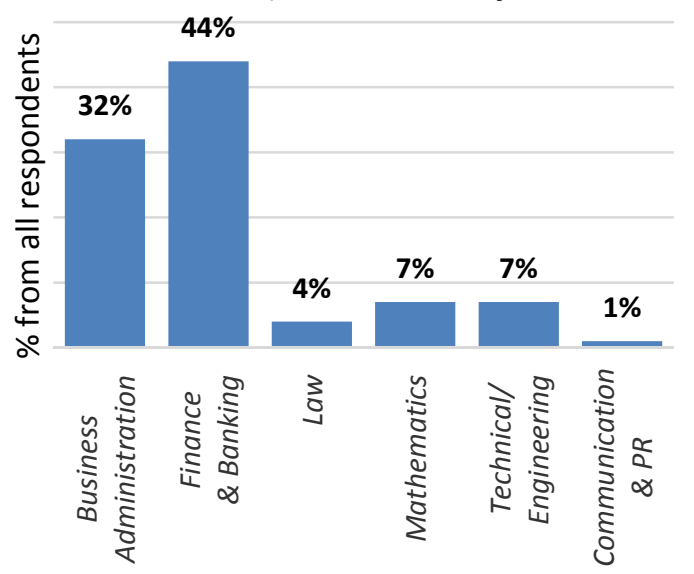

Figure 2. Managerial characteristics of respondents

As shown in Figure 2c, the level of education of respondents is mainly Master or equivalent (over $80 \%$ ). The main domain for their bachelor studies is Banking \& Finance with more than $40 \%$, followed by Business Administration with around 30\% (Figure 2d). For the reason that some managers may have two or more bachelor degrees, as well as because of the diversity of the graduate study domains, we will not study managerial view differences concerning the graduation domain of our managers. In conclusion, of the four characteristics of our respondents, depicted in Figure 2, only the age and the experience in managerial position we have considered in the statistical analysis.

DE GRUYTER OPEN 
All responses were gathered via Survey Monkey during a period of 4 months: from March 2014 to June 2014. The majority of our respondents prefer to have their data kept confidential, therefore we will not mention the names of the surveyed banks.

As already stated, the aim of this study is to research SM practice in the banking industry and to analyze the managerial view and approach toward SM issues. We found lots of studies on the topic of SM from the customers' point of view (see all sources mentioned in Table 2). Our research studies SM usage in banks and shows the view inside them, especially the managerial view with its recognition toward SM barriers, challenges, benefits.

We have paid attention to SM issues in the level of usage and its recognition in the case of bank management. We have researched the differences on managerial views and opinions connected to their characteristics, particularly the age and experience of respondents.

The sample covered important and active banks, which are leading banks in their countries and we estimate that the collected data is adequate for a qualitative research. The survey was done in 2014, which means that the data is up-to-date and presents real current use of SM and its managerial approach in Mexico. Hence, we consider the results of our research to be trustful and credible.

\section{Research Findings on Managerial Perception of Social Media use in Mexican Banks}

\subsection{Social Media presence in Mexican Banks}

Social media platforms differ from their specific features, meaning, usage and tools, and new platforms appear daily in e-horizon. Based on overall statistics we selected and developed a list of the most popular social media platforms (including the leading ones) and found out the overall social media platform usage in Mexico.

The leading platform for the Mexican surveyed banks is Twitter with a percentage of $71.1 \%$, followed by Facebook with $68.4 \%$ of usage (see Figure 3 ). We can observe that in the Mexican banking system Facebook is not in a leading position.

We created in the questionnaire a list containing the most used 19 platforms, but only 10 of them are used in Mexican banks enclosed in our survey. By studying the presence of Mexican banks in Social Media platforms, we can assert the following finding: There is a lot of room for extending the banks presence in Social Media in Mexico.

DE GRUYTER OPEN
Timisoara Journal of Economics and Business | ISSN: 2286-0991 | www.tjeb.ro Year 2014 | Volume 7 | Issue 2 | Pages: 147-174 


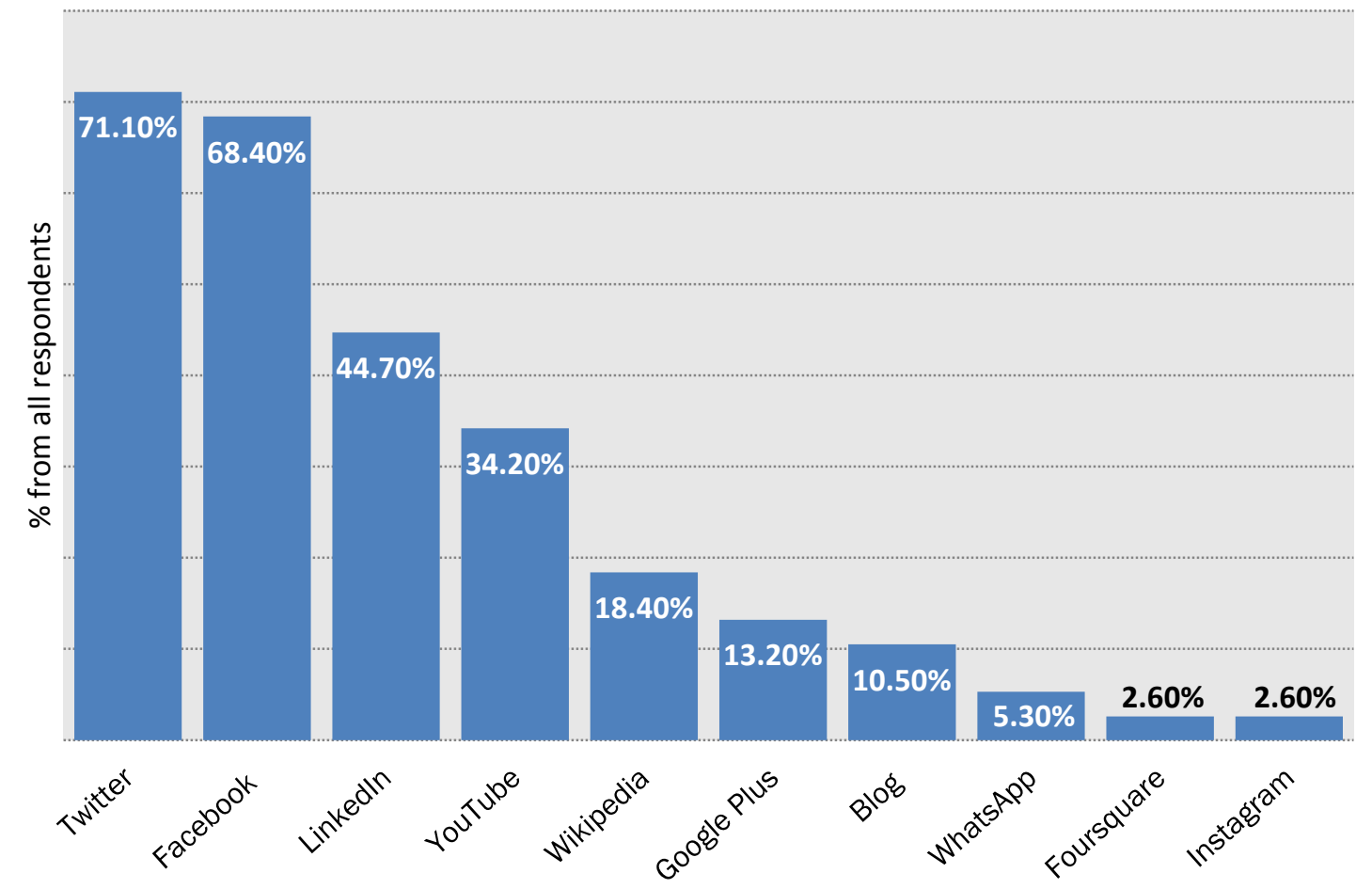

Figure 3. Hierarchy of Social Media platforms used by Mexican banks

Source: authors' representation, based on our survey data

\subsection{Barriers in Social Media adoption}

Social media adoption brings lots of barriers and difficulties for banks which are discussed in the theoretical part. For our survey, we paid attention to barriers which we considered that are more connected with internal factors, especially management related barriers. Thus, we provided the following list of barriers (including the possibility to add comments and other potential barriers - option that was not used by our interviewed):

1. Lack of senior management understanding,

2. Lack of a dedicated Social Media manager,

3. Lack of skills and competencies within banks,

4. Lack of strategy around the "usage" of Social Media.

We researched the four barriers one by one and as a single group. Separately, we surveyed how they are considered and perceived by managers having different characteristics. To test it, we used the factor analysis test, the matrix revealing that all barriers are closer in components. After that, a reliability analysis producing 0.742 for Cronbach's Alpha, conducted

\section{OPEN}


Dănăiață, D., Margea, C., Kirakosyan, K., Negovan, A.-M.

us to the consideration of grouping all those barriers into a single one. As a group, we investigated how they affect other variables and on which ones they depend.

Hypothesis 2 (H2): The banks' managers do consider that social media adoption is affected by a set of barriers.

As Figure 4 illustrates, the majority of the managers agreed and strongly agreed with the proposed set of barriers (there was the possibility to add other barriers, but they did not). The most recognized barrier was Lack of a dedicated SM manager. Indeed, this is an aspect that affects the process of implementation and of using with best results the Social Media platforms in the banking system. Among the forty interviewed managers, only two were Social Media dedicated managers, all the others took this responsibility together with others from their main area of decision (IT, Marketing or other departments).

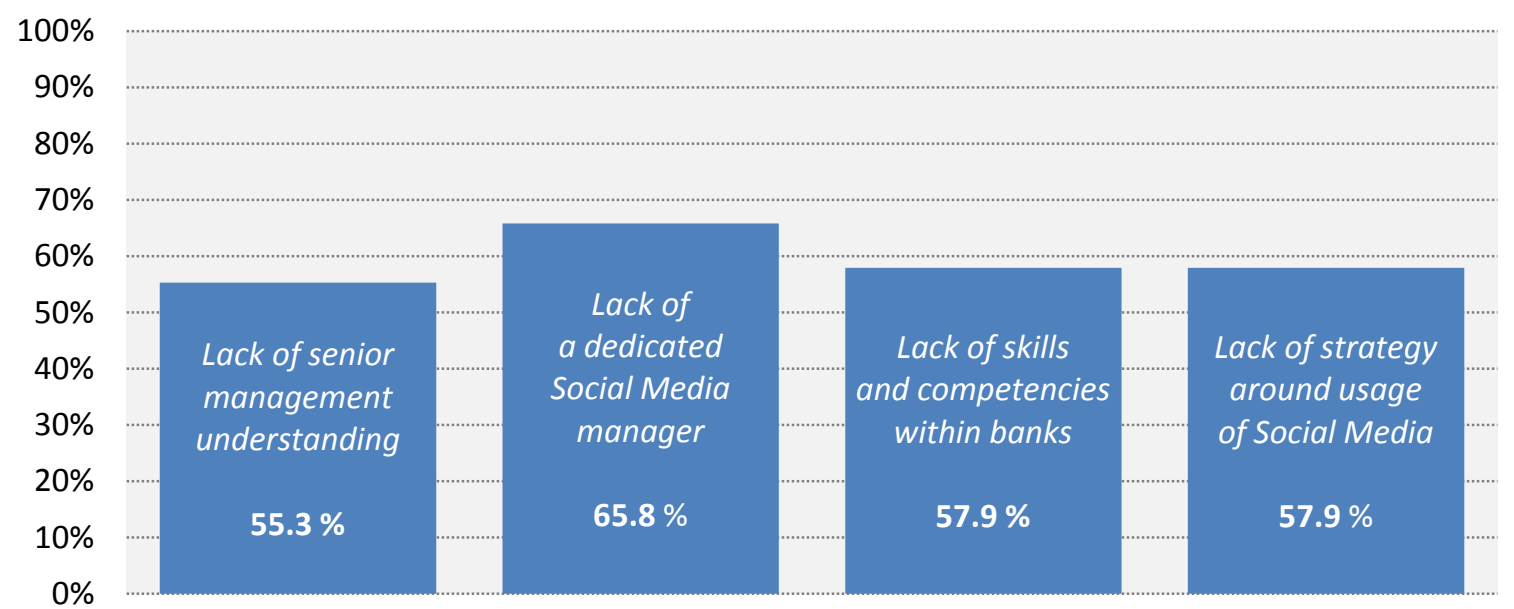

Figure 4. Managerial perception regarding the barriers on SM adoption by Mexican banks

Source: authors' representation, based on our survey data

Hypothesis 2a) (H2a): The managers' age is a factor that influences how they perceive barriers.

Figure 5 illustrates the differences in perceiving barriers between the two age groups (managers below and over age 35): managers of an age over 35 perceive barriers in a higher degree than younger managers in the first age group.

DE GRUYTER OPEN 


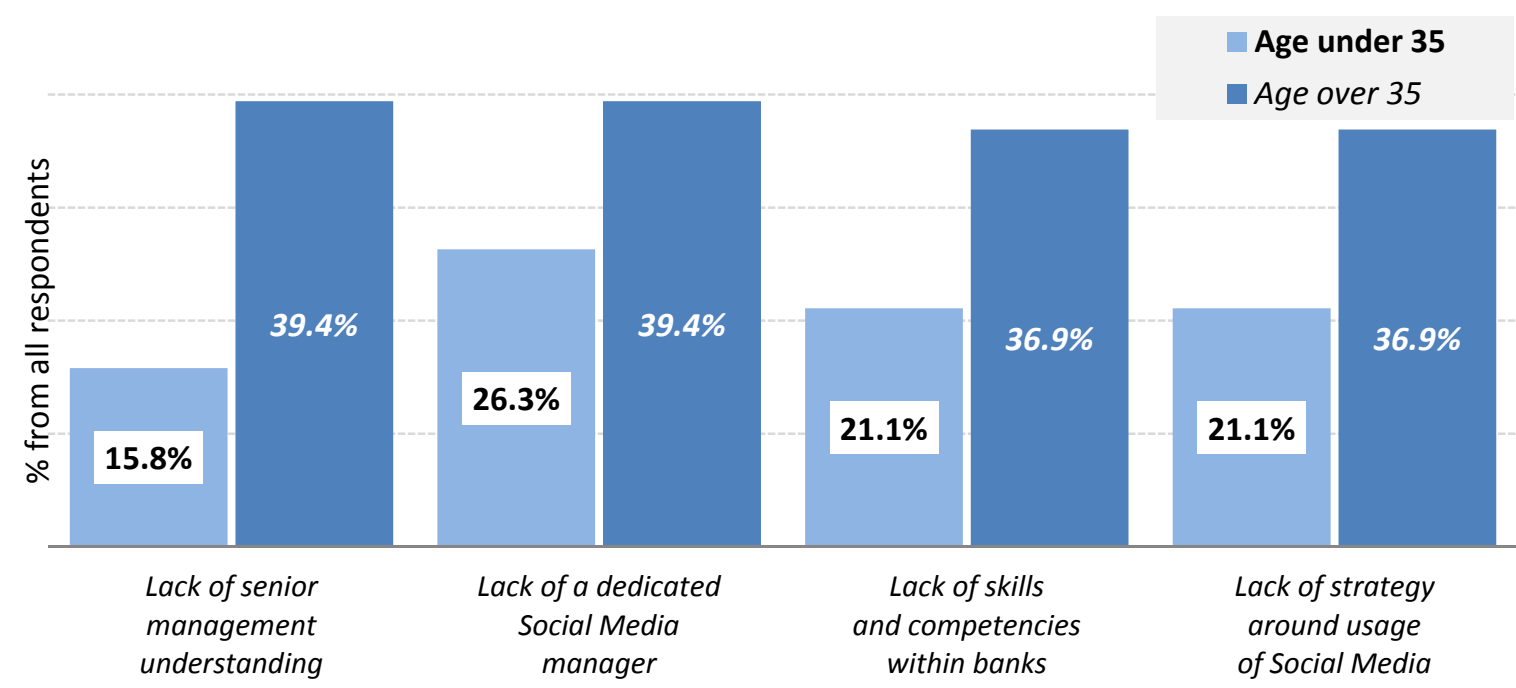

Figure 5. Age influence in how barriers are perceived

Source: authors' representation, based on our survey data

Hypothesis 2b) (H2b): The managers' experience is a factor that influences how they percieve barriers.

The differences in perceiving barriers between the two groups of experience (less than 5 and over 5 years) revealed that managers having less experience perceive barriers in a higher degree compared to managers in the second group who have more experience in a managerial position (Figure 6).

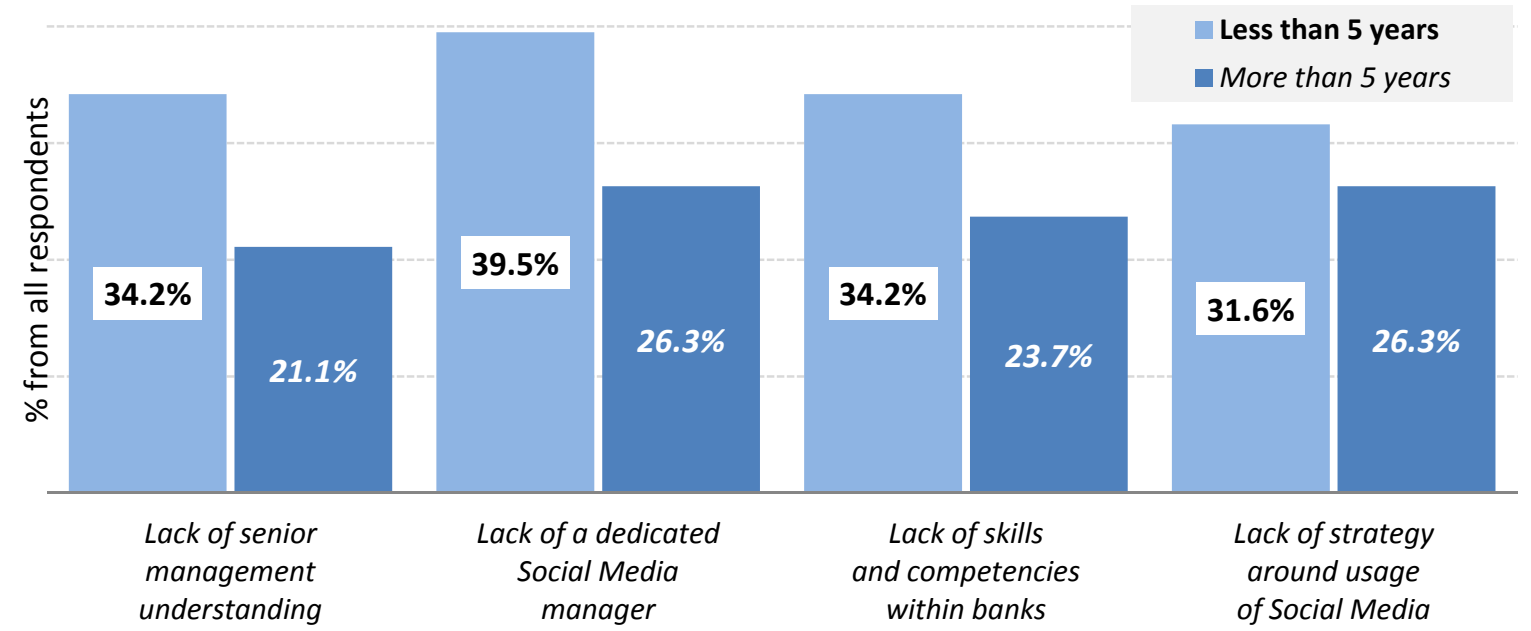

Figure 6. Experience influence in how barriers are perceived

Source: authors' representation, based on our survey data

DE GRUYTER OPEN 
Dănăiață, D., Margea, C., Kirakosyan, K., Negovan, A.-M.

Social Media in Banking. A Managerial Perception from Mexico

By studying responses regarding barriers, in correlation with age and experience, we can assert the following:

Finding: Age and experience are factors that influence how barriers are perceived by managers.

\subsection{Challenges in Social Media adoption}

No doubt, social media brings many more challenges than the ones which we set in our questionnaire, but based on our research we have chosen the following:

1. Potential customer attainability in an easy and fast way,

2. Innovative method for marketing activities,

3. Advanced way for crowdsourcing,

4. Fast way for the new competitors' and market's tracking,

5. Customer care improvement,

6. Customers' demand and behavior recognition.

We studied all challenges separately and in one group. First, we investigated how each challenge is considered and perceived by managers having different characteristics. As well, we gathered all variables into a single variable and studied its influence and dependence on other factors. For that, we grouped all challenges into a single one and tested it in factor and reliability analyses. That analysis gave as the idea that in matrix all components are closer, thus can be grouped into one. In the reliability statistics, Cronbach's Alpha is 0.836 (Appendix 2). After statistically testing the correctness of our variables as a single one, we transformed them and computed variables.

Hypothesis 3 (H3): The banks' managers consider that social media adoption brings a set of challenges for their banks.

As it can be seen in Figure 7, the entire set of challenges tested in our survey (managers had the possibility to add others, but they did not) was accepted in a high degree.

DE GRUYTER OPEN
Timisoara Journal of Economics and Business | ISSN: 2286-0991 | www.tjeb.ro Year 2014 | Volume 7 | Issue 2 | Pages: 147-174 
Dănăiață, D., Margea, C., Kirakosyan, K., Negovan, A.-M. of Economics and Business

Social Media in Banking. A Managerial Perception from Mexico

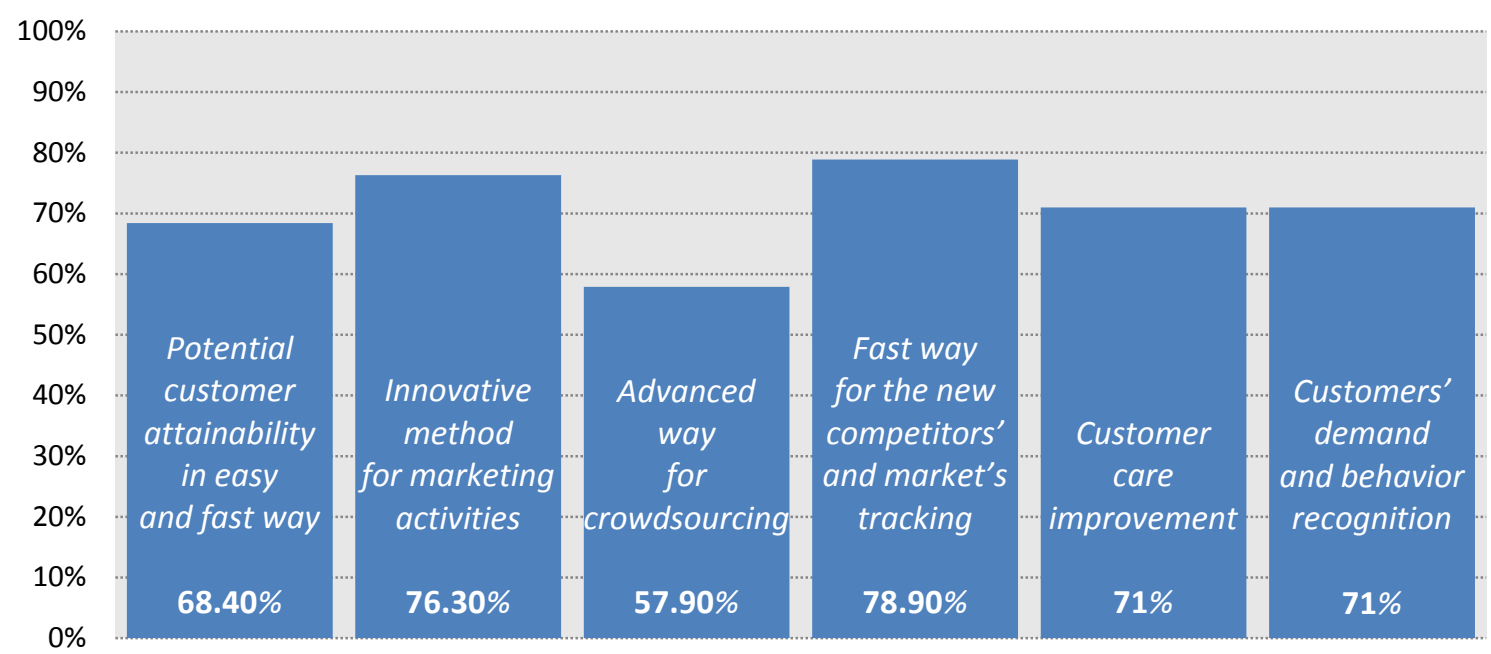

Figure 7. Managerial perception regarding the challenges in SM adoption in Mexican banks

Source: authors' representation, based on our survey data

In analyzing the way the challenges are perceived by the banks' managers, we wanted to see if the managers' age and experience influence their perception of challenges. Therefore, we tested the hypotheses H3a and $\mathbf{H 3} \mathbf{b}$.

Hypothesis 3a) (H3a): The managers' age is a factor that influences how they perceive challenges.

Hypothesis 3b) (H3b): The managers' experience is a factor that influences how they perceive challenges.

The results regarding how bank managers perceive the proposed set of challenges taking in consideration the two age groups and the two groups of experience are presented in the same way for challenges as we did for barriers in Figure 8 and Figure 9.

Our study revealed important differences between the two age groups, regarding the level of challenges perception. Since managers with an age over 35 perceive challenges in a higher degree (almost doubled for each type of challenge) than younger managers in the first age group (Figure 8).

It can be seen that the analysis of the way the level of experience influences the degree of challenge perception, managers with less experience (belonging to the group of less than 5 years' experience) pay careful attention to the set of challenges related to the ones holding a lot more experience (belonging to the group of over 5 years' experience). By comparison with the age criterion, we notice that in the case of the experience criterion the differences are not so large between the two groups.

\section{DE GRUYTER}

\section{OPEN}

Timisoara Journal of Economics and Business | ISSN: 2286-0991 | www.tjeb.ro

Year 2014 | Volume 7 | Issue 2 | Pages: 147-174 
Dănăiață, D., Margea, C., Kirakosyan, K., Negovan, A.-M.

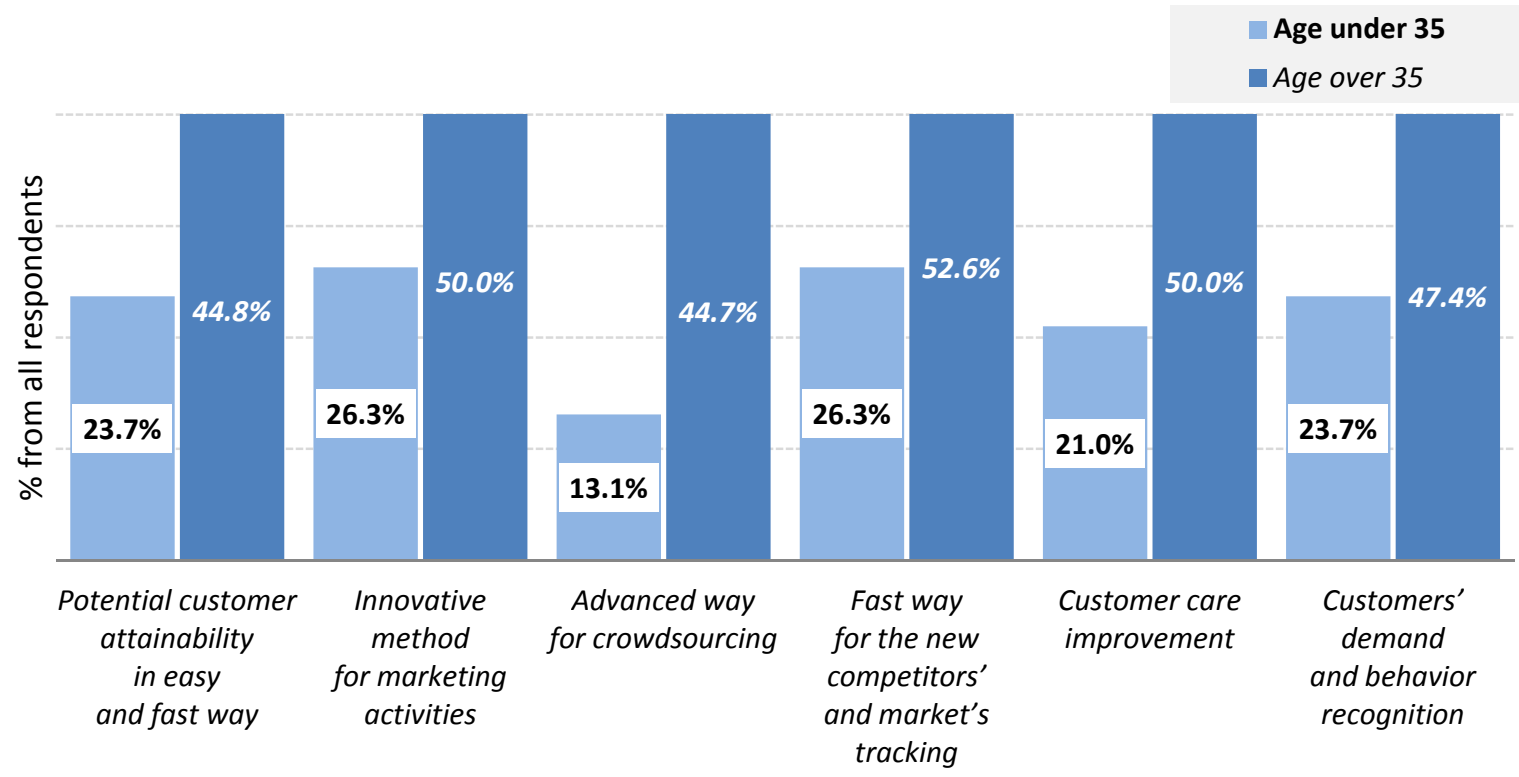

Figure 8. Age influence in how challenges are perceived

Source: authors' representation, based on our survey data

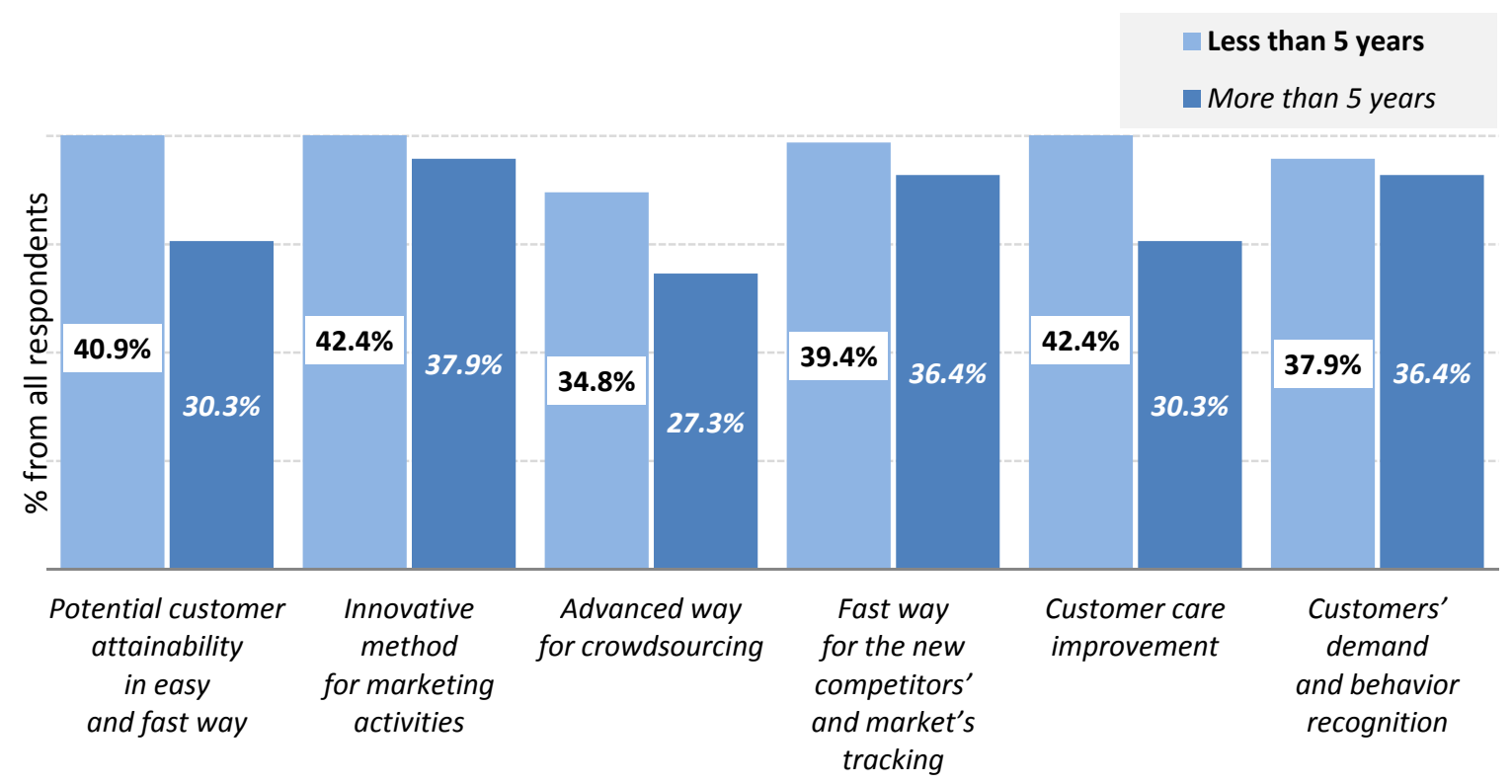

Figure 9. Experience influence in how challenges are perceived

Source: authors' representation, based on our survey data

DE GRUYTER OPEN 
Dănăiață, D., Margea, C., Kirakosyan, K., Negovan, A.-M. of Economics and Business

Social Media in Banking. A Managerial Perception from Mexico

In conclusion, by studying challenges in correlation with managers' age and experience, we can assert the following finding.

Finding: Age and experience are factors that influence how challenges are perceived.

\subsection{Influences between Social Media Barriers and Social Media Challenges}

In order to test our hypothesis we had to compute two new variables from 10 existing variables. The four variables used for barriers were: lack of senior management understanding, lack of a dedicated Social Media manager, lack of skills and competencies within banks and lack of strategy around the "usage" of Social Media. The six variables used for challenges were: potential customer attainability in an easy and fast way, innovative method for marketing activities, advanced way for crowdsourcing, fast way for the new competitors' and market's tracking, customer care improvement, customers' demand and behavior recognition. Before computing a new variable from existing variables we conducted two statistical analyses: factor reduction and reliability analysis.

For SM barriers, in factor reduction we had a table including total variance explained where we looked at Initial Eigen values. We had four factors (the ones mentioned above) and only one of them had a value higher than one. That means that only one factor ties the variables together. Only the variable that registers a high score will be combined in the future computed variable. In the component matrix, all values were over 0.7. So, all of the selected variables will be included in the second test: the reliability analysis.

We conducted a reliability analysis to see what would happen if we deleted one factor from our future computed variable. The value of Cronbach Alpha is 0.742 (see Appendix 1). We compared this value with the one found for each variable in the column Cronbach Alpha if item deleted. If there was any value above our Alpha then we would exclude the factor from our future computed variable. Because all four values are below 0.742 , to form a single scale we can compute a new variable called SM barriers, as shown in the above formula.

$$
\begin{aligned}
\text { SM barriers }= & \text { (Lack of senior management understanding } \\
& + \text { Lack of a dedicated Social Media manager } \\
& + \text { Lack of skills and competencies within banks } \\
& + \text { Lack of strategy around "usage" of Social Media)/4 }
\end{aligned}
$$

For SM challenges we performed the same two analysis using the variables for challenges. In the first test for factor reduction, the results we obtained conducted us to the elimination of the variable: innovative method for marketing activities. The second analysis for factor reduction was successful and only one factor was higher than one. All the results in the component matrix indicated that we can perform the reliability analysis.

The reliability analysis conducted to see what would happen if we deleted one item confirmed that we can create a new scale variable SM challenges from our multiple

\section{DE GRUYTER OPEN}


Dănăiață, D., Margea, C., Kirakosyan, K., Negovan, A.-M.

response set. The value of Cronbach Alpha was of 0.836 (see Appendix 2). Only one of the remaining variables scored a slightly higher Cronbach Alpha. We considered that this had no significant influence on the new variable so we can compute it using the following formula:

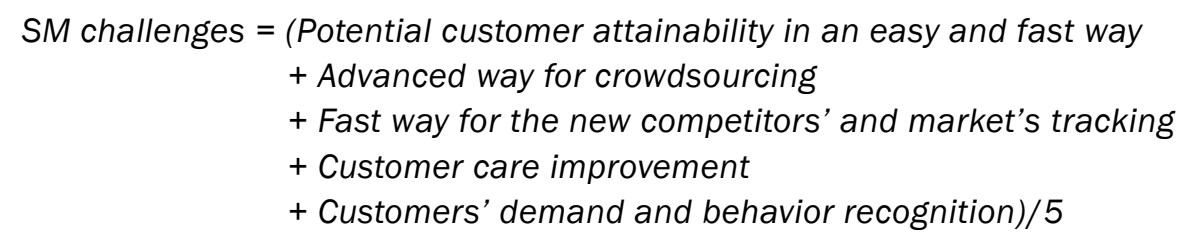

Using the two new computed variables we conducted a bivariate analysis to see if SM barriers had any influence on SM challenges. As can be seen in Table 4, the value of Pearson's coefficient is below 0.5. So there is an influence between the two factors, but it isn't a strong one.

Table 4. Correlation between barriers and challenges in Social Media adoption

\begin{tabular}{|c|c|c|c|}
\hline & & $\begin{array}{l}\text { Computed variable for } \\
\text { barriers in SM adoption }\end{array}$ & $\begin{array}{l}\text { Computed variable for } \\
\text { challenges in using SM }\end{array}$ \\
\hline \multirow{3}{*}{$\begin{array}{l}\text { Computed variable for } \\
\text { barriers in SM adoption }\end{array}$} & Pearson Correlation & 1 & $.418^{*}$ \\
\hline & Sig. (2-tailed) & & .017 \\
\hline & $\mathrm{N}$ & 36 & 32 \\
\hline \multirow{3}{*}{$\begin{array}{l}\text { Computed variable for } \\
\text { challenges in using SM }\end{array}$} & Pearson Correlation & $.418^{*}$ & 1 \\
\hline & Sig. (2-tailed) & .017 & \\
\hline & $\mathrm{N}$ & 32 & 32 \\
\hline
\end{tabular}

*Correlation is significant at the 0.05 level (2-tailed)

Because the Sig value from our t test is low (.017), we can't say with certainty that the barriers don't influence how our respondents perceive the future challenges.

By conducting the GLM test we found that SM barriers perception is connected to how SM challenges are considered and recognized among managers. The result is that barriers depend on challenges with high signification 0.029 (Phi Cramer's). (Appendix 3)

We conducted also the GLM tests and found that the perception of SM challenges depends on how SM barriers are considered and recognized among managers. The signification of this dependence is pretty high; the challenge dependence on barriers is 0.034 (Phi Cramer's). (Appendix 4)

Finding: Social media challenges and barriers depend on and influence one another. 


\section{Conclusions, Limits of the Study and Further Research}

By conducting research in 20 Mexican banks among 40 bank managers, we concluded that the Mexican banking system has a good presence in social media platforms by using it for different purposes, but there is a lot of room for extending the banks' presence in Social Media.

From a managerial point of view, in general the managers do recognize the power of social media in their banks. Based on our study, the managers' age and experience in managerial position in SM area are two factors that influence the degree of perception of barriers and challenges in adopting Social Media in the Mexican banking system.

Table 5 presents all tested hypotheses with explanation and level of validation. From three main and four sub-hypotheses, almost all were validated - only one was partially validated (H1).

Table 5. Hypotheses with validations

\begin{tabular}{|c|c|c|}
\hline Hypothesis & Explanation & Validation \\
\hline H1 & $\begin{array}{l}\text { The banks in Mexico are present in Facebook, Linkedln, Twitter, YouTube, } \\
\text { Blog, Wikipedia, and Google Plus. } \\
\text { We put in our list most used } 19 \text { platforms, but only } 10 \text { of them are used } \\
\text { by Mexican banks. } \\
\text { The leading platform in Mexican banks is Twitter (71.1\%). }\end{array}$ & $\begin{array}{l}\text { Partially } \\
\text { validated }\end{array}$ \\
\hline H2 & $55.3 \%$ of our respondents agree with the set of barriers & Validated \\
\hline $\mathrm{H} 2 \mathrm{a}$ & $\begin{array}{l}\text { In Mexican banks, SM barriers are much stronger perceived by managers } \\
\text { over } 35 .\end{array}$ & Validated \\
\hline $\mathrm{H} 2 \mathrm{~b}$ & $\begin{array}{l}\text { In Mexican banks, managers having less than } 5 \text { year experience allot } \\
\text { more signification to SM barriers. }\end{array}$ & Validated \\
\hline H 3 & $\begin{array}{l}\text { Managers from Mexican banks confer a big importance to all challenges } \\
\text { in the range of } 63-84 \% \text {. }\end{array}$ & Validated \\
\hline H3a & $\begin{array}{l}\text { In Mexican banks, older manager allot more signification to social media } \\
\text { challenges than younger ones do. }\end{array}$ & Validated \\
\hline H3b & $\begin{array}{l}\text { In Mexican banks, the perception among the } 2 \text { groups of experience } \\
\text { (less than } 5 \text { years and over } 5 \text { years) is very closely related. }\end{array}$ & Validated \\
\hline
\end{tabular}

As social media does not have borders and limits, its usage is worldwide. We have investigated its impact only in one country, which can be a limitation of the current research. A comparative research, involving other countries, could bring the confirmation of the conclusions' validity and also could emphasize possible differentiations among managers' perception in different countries.

\section{DE GRUYTER OPEN}

Timisoara Journal of Economics and Business | ISSN: 2286-0991 | www.tjeb.ro Year 2014 | Volume 7 | Issue 2 | Pages: 147-174 
Dănăiață, D., Margea, C., Kirakosyan, K., Negovan, A.-M. of Economics and Business

Social Media in Banking. A Managerial Perception from Mexico

This is why we continued our research in other two countries (Armenia and Romania) and presented further comparative results regarding SM usage in different banking systems (Kirakosyan, 2014 a; Kirakosyan, 2014 b).

\section{Acknowledgement:}

We would like to address our thanks to the anonymous reviewers, for useful comments and suggestions. We are also deeply grateful to Monica Boldea - the language advisor that professionally, thoroughly and promptly helped us in the linguistic finishing of this paper. Any remaining errors or omissions are solely the authors' responsibility.

\section{References}

Australian Independent Business Media (AIBM) Pty Ltd. (2014). Business Spectator. Retrieved from http://www.businessspectator.com

Berg, J. (2013). Social Media Most Likely to Lead to Your Bank's Next Sale. Retrieved from http://www.americanbanker.com/magazine/123_8/social-media-most-likely-tolead-to-your-banks-next-sale-1060532-1.html

Brown, D. (2012). Social Media ROI is Still a Challenge for 57\%. Retrieved September 11, 2012, from http://www.convinceandconvert.com/social-media-research-2/new-rese arch-social-media-roi-is-still-a-challenge-for-57/?utm_source=Webbiquity

Brown, L. (2010, September 22). Social Media Are Coming of Age in the Business World: Companies Here and Nationally Are Beefing Up Their Networking Staffs. St. Louis Post-Dispatch. Retrieved from http://www.stltoday.com/business/article_4496 a1bd-0348-5cc6-821d-382a9f48e8fa.html

Bussmann, J., Hyde, P., \& Sandrock, J. (2011). Banking on Social Media: Retail banks can use Facebook, YouTube, and other new platforms to better reach their "Generation C" customers. Retrieved from http://www.strategy-business.com/article/11202?pg=all

Camhi J. (2013). 2014 Forecast: The Evolution of Social Media in Banking. Retrieved from http://www.banktech.com/channels/2014-forecast-the-evolution-of-social-mediain-banking/d/d-id/1296744?

Das, S. R., \& Chen, M. Y. (2007). Yahoo! for Amazon: sentiment extraction from small talk on the web. Management Science, 53(9), 1375-1388. doi:10.1287/mnsc.1070.0704

Dominguez, C. (2013, July 25). Leveraging social media: a communications tool for heads of state in Latin America. Diplomatic Courier. Retrieved from http://www.diplomati courier.com/news/regions/latin-america/1606-leveraging-social-media-acommunications-tool-for-heads-of-state-in-latin-america

Edosomwan S., Prakasan S. K., Kouame D., Watson J., \& Seymour, T. (2011). The History of Social Media and its Impact on Business. The Journal of Applied Management and Entrepreneurship, 16(3), 79-91.

Efma \& Wipro. (2013). The Global Retail Banking Digital Marketing Report 2013: How digital technologies, social media and the explosion of data are redefining customer engagement models. Efma and WIPRO, Report May 2013. Retrieved from http://www.wipro.com/Documents/the-global-retail-banking-digital-marketingreport-2013.pdf

DE GRUYTER OPEN 
Dănăiață, D., Margea, C., Kirakosyan, K., Negovan, A.-M.

Social Media in Banking. A Managerial Perception from Mexico

Ernst\&Young. (2012a). Global banking outlook: 2013-14, Banking and the global economy. Retrieved from http://www.ey.com/GL/en/Industries/Financial-Services/Banking--Capital-Markets/Global-banking-outlook-2013-14--Banking-and-the-globaleconomy

Ernst\&Young. (2012b). Social media strategy, policy and governance. EYGM

Ernst\&Young. (2012c). Global Consumer Banking Survey 2012. The customer takes control. Retrieved from http://www.ey.com/Publication/vwLUAssets/Global_Consumer_ Banking_Survey_2012_The_customer_takes_control/\$FILE/Global_Consumer_Ban king_Survey_2012.pdf

Hensel, K. \& Deis, M. (2010). Using social media to increase advertising and improve marketing. The Entrepreneurial Executive, 15, 87-97.

Instituto Nacional de Estadística y Geografía (INEGI). (2014). http://www.inegi.org.mx/

Jiang, C., Liang, K., Chen, H., \& Ding, Y. (2013). Analyzing market performance via social media: a case study of a banking industry crisis. Sci. China Inf. Sci., 57(5), 1-18. doi:10.1007/s11432-013-4860-3

Kaplan, A. M., \& Haenlein, M. (2010). Users of the world, unite! The challenges and opportunities of Social Media. Business Horizons, 53(1), 59-68. doi:10.1016/j.bushor.2009.09.003

Khanal, Bh. (2013). Why banks need to embrace social media? Retrieved from http://www.informationweek.in/informationweek/perspective/271898/banksembrace-social-media

Kietzmann, J. H., Hermkens, K., McCarthy, I. P., \& Silvestre, B. S. (2011). Social media? Get serious! Understanding the functional building blocks of social media. Business Horizons, 54(3), 241-251. doi:10.1016/j.bushor.2011.01.005

King, B. (2013). Bank 3.0: Why banking is no longer somewhere you go, but something you do. Singapore: Marshall Cavendish Editions.

Kirakosyan, K. (2014 a). A Managerial View of Social Media Usage in Banking. Comparative Study for Armenian and Romanian Banking Systems. ISI Proceedings of the 24th IBIMA Conference: Crafting Global Competitive Economies: 2020 Vision Strategic Planning \& Smart Implementation, Milan, Italy, ISBN:978-0-9860419-3-8, available online at http://www.ibima.org/ITALY2014/papers.html

Kirakosyan, K. (2014 b). Managerial Perspective on Social Media Implementation in Banking Industry: Comparative Study on Romanian and Mexican Banks. Review of International Comparative Management, 15(3), 297-311. Retrieved from http://www.rmci.ase.ro/no15vol3/04.pdf

Lemon, K. N., \& Rust, R. T. (2001). E-service and the consumer. International Journal of Electronic Commerce, 5, 85-101.

Leonard, D., \& Youra, B. (2013). Banks: Stop Missing Sales Opportunities. Retrieved from http://thegallupblog.gallup.com/2013/05/banks-stop-missing-sales-opportunities. html

Menéndez, P., \& Enríquez, E. (2014). Estudio sobre los hábitos de los usuarios de internet en México 2014. Asociación Mexicana de Internet (AMIPCI). Retrieved from https://www.amipci.org.mx/estudios/habitos_de_internet/Estudio_Habitos_del_In ternauta_Mexicano_2014_V_MD.pdf

Merrill, T., Latham, K., Santalesa, R., \& Navetta, D. (2011). Social Media: The Business Benefits May Be Enormous, But Can the Risks -Reputational, Legal, Operational -Be Mitigated? INFORMATIONLAWGROUP OPEN 
Dănăiață, D., Margea, C., Kirakosyan, K., Negovan, A.-M.

Social Media in Banking. A Managerial Perception from Mexico

Moreno L. (2012, November, 13) How Social Media Could Revolutionize Third-World Cities, The Atlantic. Retrieved from http://www.theatlantic.com/international/archive/ 2012/11/how-social-media-could-revolutionize-third-world-cities/265135

Nadkarni, S. (2013). Avoiding Social Media Will Cost Banks Customers. Retrieved from http:/www.americanbanker.com/bankthink/avoiding-social-media-will-cost-bankscustomers-1059853-1.html

Paridon, T. \& Carraher, S.M. (2009). Entrepreneurial marketing: Customer shopping value and patronage behavior. Journal of Applied Management \& Entrepreneurship, 14 (2), 3-28.

Pearson, M. (2013). Social Media Can Play a Role in Business Process Management. Harvard Business Review. Retrieved from http://blogs.hbr.org/2013/01/social-media-canplay-a-role

Polites, H. (2012). NAB gets serious about social. Business Spectator. Retrieved from http://www.businessspectator.com.au/article/2012/12/4/technology/nab-getsserious-about-social

Samuel, A. (2013). How to Make Space for Social Media. Harvard Business Review. Retrieved from http://blogs.hbr.org/2013/03/how-to-make-space-for-social-m

Sheng, Y. P. (2002). A business model and framework for electronic customer relationship management. Proceedings of the 8th AMCIS Conference

Shetty, R. (2013). Social Media in Financial Markets: Fact or Fiction? Banking View. Retrieved from http://blogs.sap.com/banking/2013/06/18/social-media-in-financial-marketsfact-or-fiction

Smith, N., Wollan, R., \& Zhou, Ca. (2011). The Social Media Management Handbook: Everything You Need to Know to Get Social Media Working in Your Business. Accenture, New Jersey: John Wiley \& Sons.

Tetlock, P., Saar-Teschansky, M., \& Macskassy, S. (2008). More than words: quantifying language to measure firms' fundamentals. The Journal of Finance, 63(3), 14371467. DOI: $10.1111 /$ j.1540-6261.2008.01362.x

Thomas, L. M. (2010). Sending marketing messages within social networking. Journal of Internet Law, 14(1) July, 3-4.

Toffler, A. (1980). The third wave: The classic study of tomorrow. New York: Bantam Books.

Vaynerchuk, G. (2011). The Thank You Economy. New York: Harper Collins Publisher.

We Are Social Ltd. (2014). Global Digital Statistics 2014. We Are Social's Snapshot of Key Digital Indicators. Retrieved from http://wearesocial.net/blog/2014/01/socialdigital-mobile-worldwide-2014

World Population Statistics. (2014, March 20). Population of Mexico 2014. Retrieved from http://www.worldpopulationstatistics.com/population-of-mexico-2014 
Dănăiață, D., Margea, C., Kirakosyan, K., Negovan, A.-M.

Social Media in Banking. A Managerial Perception from Mexico

\section{Appendix 1 \\ Factor and reliability analyses for Barriers group}

Factor Analysis

\begin{tabular}{lcc}
\multicolumn{2}{c}{ Communalities } & \\
\hline & Initial & Extraction \\
\hline Lack of senior management understanding. & 1.000 & .471 \\
Lack of a dedicated Social Media manager. & 1.000 & .658 \\
Lack of skills and competencies within banks. & 1.000 & .631 \\
Lack of strategy around "usage" of Social Media. & 1.000 & .529 \\
\hline
\end{tabular}

Extraction Method: Principal Component Analysis.

Total Variance Explained

\begin{tabular}{crrrrrr}
\hline \multirow{2}{*}{ Component } & \multicolumn{3}{c}{ Initial Eigenvalues } & \multicolumn{3}{c}{ Extraction Sums of Squared Loadings } \\
\cline { 2 - 6 } & \multicolumn{1}{c}{ Total } & \% of Variance & Cumulative \% & Total & \% of Variance & Cumulative \% \\
\hline $\mathbf{1}$ & 2.289 & 57.236 & 57.236 & 2.289 & 57.236 & 57.236 \\
$\mathbf{2}$ & .752 & 18.806 & 76.042 & & & \\
$\mathbf{3}$ & .537 & 13.418 & 89.460 & & & \\
$\mathbf{4}$ & .422 & 10.540 & 100.000 & & & \\
\hline
\end{tabular}

Extraction Method: Principal Component Analysis.

Component Matrix ${ }^{\text {a }}$

\begin{tabular}{lc}
\hline & Component \\
\cline { 2 - 2 } & $\mathbf{1}$ \\
\hline Lack of senior management understanding. & .686 \\
Lack of a dedicated Social Media manager. & .811 \\
Lack of skills and competencies within banks. & .794 \\
Lack of strategy around "usage" of Social Media. & .727 \\
\hline
\end{tabular}

Extraction Method: Principal Component Analysis.

a. 1 components extracted.

Reliability analysis

\begin{tabular}{llrr}
\multicolumn{5}{c}{ Case Processing Summary } \\
\hline \multirow{3}{*}{ Cases } & $N$ & $\%$ \\
& Valid $^{*}$ & 36 & 90.0 \\
& Excluded $^{\text {a }}$ & 4 & 10.0 \\
& Total $^{*}$ & 40 & 100.0 \\
\hline
\end{tabular}

a. List wise deletion based on all variables in the procedure.

Reliability Statistics

\begin{tabular}{cc}
\hline Cronbach's Alpha & $\mathrm{N}$ of Items \\
\hline .742 & 4 \\
\hline
\end{tabular}

Item-Total Statistics

\begin{tabular}{lcccc}
\hline & $\begin{array}{c}\text { Scale Mean } \\
\text { if Item Deleted }\end{array}$ & $\begin{array}{c}\text { Scale Variance } \\
\text { if Item Deleted }\end{array}$ & $\begin{array}{c}\text { Corrected Item- } \\
\text { Total Correlation }\end{array}$ & $\begin{array}{c}\text { Cronbach's Alpha } \\
\text { if Item Deleted }\end{array}$ \\
\hline Lack of senior management understanding. & 10.67 & 5.943 & .465 & .734 \\
Lack of a dedicated Social Media manager. & 10.44 & 6.025 & .601 & .644 \\
Lack of skills and competencies within banks. & 10.58 & 6.364 & .596 & .652 \\
Lack of strategy around "usage" of Social Media. & 10.47 & 6.656 & .501 & .701 \\
\hline
\end{tabular}

DE GRUYTER OPEN 


\section{Appendix 2 \\ Factor and reliability analyses for Challenges group}

Factor Analysis

\begin{tabular}{|c|c|c|}
\hline \multicolumn{3}{|l|}{ Communalities } \\
\hline & Initial & Extraction \\
\hline Potential customer attainability in an easy and fast way. & 1.000 & .636 \\
\hline Innovative method for marketing activities. & 1.000 & .766 \\
\hline Advanced way for crowdsourcing. & 1.000 & .817 \\
\hline Fast way for the new competitors' and market's tracking. & 1.000 & .604 \\
\hline Customer care improvement. & 1.000 & .798 \\
\hline Customers' demand and behavior recognition. & 1.000 & .851 \\
\hline
\end{tabular}

Extraction Method: Principal Component Analysis.

Total Variance Explained

\begin{tabular}{crrrrrr}
\hline \multirow{2}{*}{ Component } & \multicolumn{3}{c}{ Initial Eigenvalues } & \multicolumn{2}{c}{ Extraction Sums of Squared Loadings } \\
\cline { 2 - 6 } & \multicolumn{1}{c}{ Total } & \% of Variance & Cumulative \% & Total & \% of Variance & Cumulative \% \\
\hline 1 & 3.307 & 55.113 & 55.113 & 3.307 & 55.113 & 55.113 \\
2 & 1.166 & 19.434 & 74.547 & 1.166 & 19.434 & 74.547 \\
3 & .592 & 9.863 & 84.410 & & & \\
4 & .381 & 6.356 & 90.766 & & & \\
5 & .359 & 5.977 & 96.743 & & & \\
6 & .195 & 3.257 & 100.000 & & & \\
\hline
\end{tabular}

Extraction Method: Principal Component Analysis.

\begin{tabular}{lrr}
\multicolumn{3}{c}{ Component Matrix } \\
& \multicolumn{2}{c}{ Component } \\
\cline { 2 - 3 } & 1 & 2 \\
\hline Potential customer attainability in an easy and fast way & .797 & .040 \\
Innovative method for marketing activities & .702 & .523 \\
Advanced way for crowdsourcing & .603 & .673 \\
Fast way for the new competitors' and market's tracking & .767 & -.125 \\
Customer care improvement & .736 & -.506 \\
Customers' demand and behavior recognition & .828 & -.408
\end{tabular}

Extraction Method: Principal Component Analysis.

a. 2 components extracted.

Total Variance Explained

\begin{tabular}{crrrrrr}
\hline Component & \multicolumn{3}{c}{ Initial Eigenvalues } & \multicolumn{3}{c}{ Extraction Sums of Squared Loadings } \\
\cline { 2 - 6 } & \multicolumn{1}{c}{ Total } & \% of Variance & Cumulative \% & Total & \% of Variance & Cumulative \% \\
\hline 1 & 2.912 & 58.248 & 58.248 & 2.912 & 58.248 & \\
2 & .940 & 18.793 & 77.042 & & & \\
3 & .591 & 11.820 & 88.862 & & \\
4 & .360 & 7.202 & 96.063 & & \\
5 & .197 & 3.937 & 100.000 & & & \\
\hline
\end{tabular}

Extraction Method: Principal Component Analysis.

DE GRUYTER OPEN
Timisoara Journal of Economics and Business | ISSN: 2286-0991 | www.tjeb.ro

Year 2014 | Volume 7 | Issue 2 | Pages: 147-174 
Dănăiață, D., Margea, C., Kirakosyan, K., Negovan, A.-M.

Social Media in Banking. A Managerial Perception from Mexico

\begin{tabular}{lc}
\multicolumn{2}{c}{ Component Matrix $^{\mathbf{a}}$} \\
\hline
\end{tabular}

Extraction Method: Principal Component Analysis.

a. 1 components extracted.

\section{Reliability analysis}

\section{Scale: ALL VARIABLES}

\begin{tabular}{llrr}
\multicolumn{4}{c}{ Case Processing Summary } \\
\hline \multirow{4}{*}{ Cases } & $\mathrm{N}$ & $\%$ \\
\cline { 2 - 4 } & Valid $^{\text {Cal }}$ & 36 & 90.0 \\
& Excluded $^{a}$ & 4 & 10.0 \\
& Total $^{4}$ & 40 & 100.0 \\
\hline
\end{tabular}

a. List wise deletion based on all variables in the procedure.

Reliability Statistics

\begin{tabular}{rr}
\hline Cronbach's Alpha & N of Items \\
.836 & 6 \\
\hline
\end{tabular}

\begin{tabular}{lcccc}
\multicolumn{4}{c}{ Item-Total Statistics } & \\
\hline & $\begin{array}{c}\text { Scale Mean } \\
\text { if Item Deleted }\end{array}$ & $\begin{array}{c}\text { Scale Variance } \\
\text { if Item Deleted }\end{array}$ & $\begin{array}{c}\text { Corrected } \\
\text { Item-Total } \\
\text { Correlation }\end{array}$ & $\begin{array}{c}\text { Cronbach's } \\
\text { Alpha if Item } \\
\text { Deleted }\end{array}$ \\
\hline $\begin{array}{l}\text { Potential customer attainability in an easy } \\
\text { and fast way. }\end{array}$ & 19.13 & 14.694 & .678 & .795 \\
$\begin{array}{l}\text { Innovative method for marketing activities. } \\
\text { Advanced way for crowdsourcing. }\end{array}$ & 18.81 & 16.093 & .570 & .818 \\
$\begin{array}{l}\text { Fast way for the new competitors' and } \\
\text { market's tracking. }\end{array}$ & 19.25 & 17.548 & .469 & .835 \\
$\begin{array}{l}\text { Customer care improvement. } \\
\text { Customers' demand and behavior }\end{array}$ & 18.97 & 15.064 & .635 & .805 \\
recognition. & 19.00 & 15.484 & .594 & .813 \\
\hline
\end{tabular}


Dănăiață, D., Margea, C., Kirakosyan, K., Negovan, A.-M. of Economics and Business

Social Media in Banking. A Managerial Perception from Mexico

\section{Appendix 3 \\ Barriers dependence on Challenges variable (GLM test)}

Factor Analysis

Univariate Analysis of Variance

Between-Subjects Factors

\begin{tabular}{lll}
\hline & & $\mathrm{N}$ \\
\hline \multirow{7}{*}{ Challenges } & .60 & 1 \\
& 3.00 & 3 \\
& 3.20 & 4 \\
& 3.40 & 3 \\
& 3.60 & 1 \\
& 3.80 & 6 \\
& 4.00 & 2 \\
& 4.20 & 5 \\
& 4.40 & 1 \\
& 4.60 & 5 \\
& 5.00 & 1 \\
\hline
\end{tabular}

\begin{tabular}{ccrr}
\multicolumn{4}{c}{ Descriptive Statistics } \\
Dependent Variable: Barriers & \multicolumn{3}{l}{} \\
\hline $\begin{array}{c}\text { Computed variable } \\
\text { for challenges in using SM }\end{array}$ & Mean & Std. Deviation & $N$ \\
\hline .60 & 2.5000 &. & 1 \\
3.00 & 2.6667 & .57735 & 3 \\
3.20 & 3.8750 & 1.05079 & 4 \\
3.40 & 3.1667 & .38188 & 3 \\
3.60 & 3.5000 &. & 1 \\
3.80 & 3.1667 & .68313 & 6 \\
4.00 & 2.3750 & .53033 & 2 \\
4.20 & 3.8500 & .45415 & 5 \\
4.40 & 4.5000 & &. \\
4.60 & 4.2500 & .61237 & 5 \\
5.00 & 3.5000 & & 1 \\
\hline Total & 3.4766 & .81903 & 32 \\
\hline
\end{tabular}

Dependent Variable: Barriers

Tests of Between-Subjects Effects

\begin{tabular}{lrrrrr}
\hline Source & Type III Sum of Squares & df & Mean Square & F & Sig. \\
\hline Corrected Model & $11.585^{\mathrm{a}}$ & 10 & 1.158 & 2.641 & .029 \\
Intercept & 233.151 & 1 & 233.151 & 531.592 & .000 \\
Challenges & 11.585 & 10 & 1.158 & 2.641 & .029 \\
Error & 9.210 & 21 & .439 & & \\
Total & 407.563 & 32 & & \\
Corrected Total & 20.795 & 31 & & \\
\hline a. R Squared $=.557$ (Adjusted R Squared $=.346)$ & & & &
\end{tabular}

Dependent Variable: Barriers

Parameter Estimates

\begin{tabular}{|c|c|c|c|c|c|c|}
\hline \multirow{2}{*}{ Parameter } & \multirow{2}{*}{$B$} & \multirow{2}{*}{ Std. Error } & \multirow{2}{*}{$t$} & \multirow{2}{*}{ Sig. } & \multicolumn{2}{|c|}{$95 \%$ Confidence Interval } \\
\hline & & & & & Lower Bound & Upper Bound \\
\hline Intercept & 3.500 & .662 & 5.285 & .000 & 2.123 & 4.877 \\
\hline [Challenges=.60] & -1.000 & .937 & -1.068 & .298 & -2.948 & .948 \\
\hline [Challenges $=3.00$ ] & -.833 & .765 & -1.090 & .288 & -2.424 & .757 \\
\hline [Challenges $=3.20$ ] & .375 & .740 & .506 & .618 & -1.165 & 1.915 \\
\hline [Challenges $=3.40$ ] & -.333 & .765 & -.436 & .667 & -1.924 & 1.257 \\
\hline [Challenges $=3.60$ ] & $-9.021 \mathrm{E}-016$ & .937 & .000 & 1.000 & -1.948 & 1.948 \\
\hline [Challenges $=3.80$ ] & -.333 & .715 & -.466 & .646 & -1.821 & 1.154 \\
\hline [Challenges $=4.00$ ] & -1.125 & .811 & -1.387 & .180 & -2.812 & .562 \\
\hline [Challenges $=4.20$ ] & .350 & .725 & .482 & .634 & -1.159 & 1.859 \\
\hline [Challenges $=4.40$ ] & 1.000 & .937 & 1.068 & .298 & -.948 & 2.948 \\
\hline [Challenges $=4.60$ ] & .750 & .725 & 1.034 & .313 & -.759 & 2.259 \\
\hline$[$ Challenges $=5.00$ ] & $0^{a}$ & & & & & \\
\hline
\end{tabular}

a. This parameter is set to zero because it is redundant.

DE GRUYTER OPEN
Timisoara Journal of Economics and Business | ISSN: 2286-0991 | www.tjeb.ro

Year 2014 | Volume 7 | Issue 2 | Pages: 147-174 


\section{Appendix 4 \\ Challenges dependence on Barriers variable (GLM test)}

Univariate Analysis of Variance

\begin{tabular}{ccc}
\multicolumn{2}{c}{ Between-Subjects Factors } \\
\hline & $N$ \\
\hline \multirow{6}{*}{ Barriers } & 2.00 & 3 \\
& 2.50 & 2 \\
& 2.75 & 3 \\
& 3.00 & 2 \\
& 3.25 & 3 \\
& 3.50 & 6 \\
& 3.75 & 3 \\
& 4.00 & 3 \\
& 4.25 & 3 \\
& 4.50 & 1 \\
4.75 & 1 \\
5.00 & 2 \\
\hline
\end{tabular}

Descriptive Statistics

Dependent Variable: Challenges

\begin{tabular}{ccrc}
\hline Barriers & Mean & Std. Deviation & $N$ \\
\hline 2.00 & 3.6000 & .52915 & 3 \\
2.50 & 1.9000 & 1.83848 & 2 \\
2.75 & 3.7333 & .30551 & 3 \\
3.00 & 3.0000 & .00000 & 2 \\
3.25 & 3.8000 & .40000 & 3 \\
3.50 & 4.1000 & .61644 & 6 \\
3.75 & 3.6000 & .34641 & 3 \\
4.00 & 4.4667 & .23094 & 3 \\
4.25 & 3.8667 & .57735 & 3 \\
4.50 & 4.4000 &. & 1 \\
4.75 & 4.6000 &. & 1 \\
5.00 & 3.9000 & .98995 & 2 \\
\hline Total & 3.7625 & .80232 & 32 \\
\hline
\end{tabular}

Tests of Between-Subjects Effects

Dependent Variable: Challenges

\begin{tabular}{lrrrrr}
\hline Source & Type III Sum of Squares & \multicolumn{1}{c}{$d f$} & Mean Square & \multicolumn{1}{c}{ F } & Sig. \\
\hline Corrected Model & $11.615^{\mathrm{a}}$ & 11 & 1.056 & 2.532 & .034 \\
Intercept & 356.824 & 1 & 356.824 & 855.692 & .000 \\
Barriers & 11.615 & 11 & 1.056 & 2.532 & .034 \\
Error & 8.340 & 20 & .417 & & \\
Total & 472.960 & 32 & & & \\
Corrected Total & 19.955 & 31 & & & \\
\hline
\end{tabular}

a. R Squared $=.582$ (Adjusted $\mathrm{R}$ Squared $=.352$ )

Parameter Estimates

Dependent Variable: Challengess

\begin{tabular}{lrrrrrr}
\hline \multicolumn{1}{c}{ Parameter } & \multirow{2}{*}{ B } & \multirow{2}{*}{ Std. Error } & \multirow{2}{*}{$t$} & \multirow{2}{*}{ Sig. } & \multicolumn{2}{c}{ 95\% Confidence Interval } \\
\cline { 5 - 7 } & & & & Lower Bound & Upper Bound \\
\hline Intercept & 3.900 & .457 & 8.541 & .000 & 2.948 & 4.852 \\
[Barriers=2.00] & -.300 & .589 & -.509 & .616 & -1.530 & .930 \\
[Barriers=2.50] & -2.000 & .646 & -3.097 & .006 & -3.347 & -.653 \\
[Barriers=2.75] & -.167 & .589 & -.283 & .780 & -1.396 & 1.063 \\
[Barriers=3.00] & -.900 & .646 & -1.394 & .179 & -2.247 & .447 \\
[Barriers=3.25] & -.100 & .589 & -.170 & .867 & -1.330 & 1.130 \\
[Barriers=3.50] & .200 & .527 & .379 & .708 & -.900 & 1.300 \\
[Barriers=3.75] & -.300 & .589 & -.509 & .616 & -1.530 & .930 \\
[Barriers=4.00] & .567 & .589 & .961 & .348 & -.663 & 1.796 \\
[Barriers=4.25] & -.033 & .589 & -.057 & .955 & -1.263 & 1.196 \\
[Barriers=4.50] & .500 & .791 & .632 & .534 & -1.150 & 2.150 \\
[Barriers=4.75] & .700 & .791 & .885 & .387 & -.950 & 2.350 \\
[Barriers=5.00] & $00^{\mathrm{a}}$ &. &. & &. &. \\
\hline
\end{tabular}

a. This parameter is set to zero because it is redundant.

DE GRUYTER OPEN
Timisoara Journal of Economics and Business | ISSN: 2286-0991 | www.tjeb.ro Year 2014 | Volume 7 | Issue 2 | Pages: 147-174 